Terbit online pada laman web jurnal : http://e-journal.sastra-unes.com/index.php/JIPS

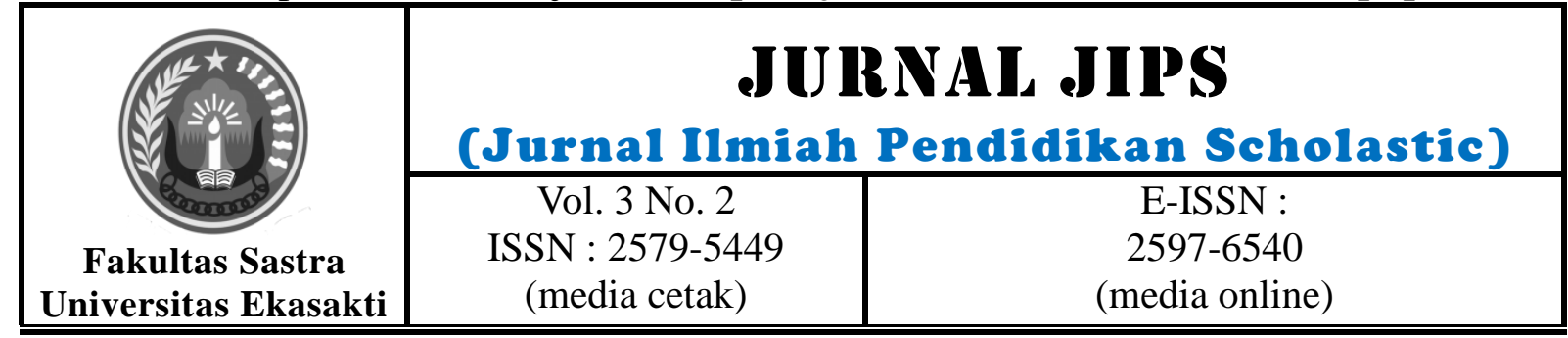

\title{
AN ANALYSIS OF STUDENTS' READING ABILITY IN IDENTIFYING GENERIC STRUCTURE OF NEWS ITEM TEXT
}

\author{
Widya Juli Astria \\ Universitas Ekasakti \\ widyajuliastria@gmail.com
}

\begin{abstract}
This research aims to determine the ability of students to identify the generic structure of the news item text. This research uses a descriptive method. Data is taken through examinations in the form of multiple choice questions. The results showed that the ability of students to identify newsworthy events, event backgrounds and sources of news item texts was at a moderate level. This is evidenced by the percentage of student scores for each of the generic structures is $58.46 \%, 69,23 \%$ and 61, 54\%. Therefore, teachers are advised to discuss more and provide training on generic structure of the news item text. Then, students are advised to study harder to understand and do generic structure exercises from news item text. Furthermore, the next researcher is expected to conduct research related to the problems faced by students in identifying the generic structure of the news item text.
\end{abstract}

Keywords: Reading, Generic Structure, News Item Text

(C) 2019Jurnal JIPS

\section{INTRODUCTION}

Reading is a language process that needs one's ability to understand and know the information provided in the passage. In other words, reading is a complicated process and there is much more to reading than recognizing printed words. Chia (2001: 22) states that in one current perspective on reading comprehension, the reading process is an interaction between a reader's prior knowledge and the information encoded in the text. This means a process that needs one's ability to understand and know the information provided in the text. It is an activity in receiving new idea, new information from printed page for intellectual growth and for mental reading.

In brief, reading can be said as an interactive communication that encompasses the background of knowledge and ability to organize the overall ideas of passage. In other words, reading is a thinking process that needs the ability to interact with passage in order to understand. As a result, the students should find themselves reading more quickly, understanding more of what they read and therefore deriving more enjoyment from their reading.

In teaching reading especially in teaching news item text, the students are required to be able to understand the news item through identifying the generic structure. As stated by Gerot and Wignell (1994) news item is as a kind of text which is used to inform readers, listeners, or viewers about events of the day which is considered newsworthy or important. White (1998) contributes his idea about news item. News item as a text type is a kind of a vital mechanism for the dissemination of information. Also, it is the subject of significant disagreement. It is common place for the media to report the 
factual production of reality. He also says that the notion of the news item should be neutral and factual. It is neutral because the news item should be written from a neutral point of view and in unbiased way.

It is factual because the news item has an important function to spread the factual information happened that is commonly used by the media in neutral and factual form. A news item should tell only the facts; it should not give an opinion. In a well-written news article, the essential facts are given in the first one or two, or lead, paragraphs, and subsequent paragraphs give the story in greater detail.

Basically, every type of writing has the same generic structure. This structure is important in helping the readers to identify the information of the text. There should be the beginning, the middle, and the end. Especially for news item, the beginning is called the news lead; the middle is news body, and the last is news foot. While the generic structures of the news item are newsworthy event, background events, and sources.

\section{RESEARCH METHODS}

This research was descriptive research. It described students' ability to identify generic structure of news item text. Gay (1987: 189) says that descriptive research involves collecting data in order to answer questions concerning the current status of the subject of the study.

The population of the research was the second year students of SMA Pertiwi 1 Padang. Gay (1987: 102) defines population as the group to which the writer would like the result of the study to be generalized. There were about 295 students who were grouped into nine classes. There were four classes of IPA and four classes of IPS. Each classes consisted of 35 to 38 students. The writer chose this population to be studied because they had learned news item at the first year.

According to Gay (1987:101) sampling is the process of selecting representative number of individuals out of a larger group. To take the sample, the writer used stratified cluster random sampling technique. Stratified means the sample is taken on the consideration of their department IPA and IPS. The writer chose stratified cluster random sampling because the population has two strata, IPA and IPS, and the population have

been grouped into classes. To select the sample the writer signed the code of each class on pieces of paper. They were rolled and mixed up into two boxes. Then the writer chose one paper from IPA box and one paper from IPS box. The selected classes were IPA3 and IPS2 as the sample. There were 65 students.

The instrument used in this study was reading news item test. It was a kind of multiple choice tests. This test consisted of four texts with 30 items for try out and 21 items for the real test. The writer took 28 students from the population to do the try out. The students were given 60 minutes to do the test. In the test the students were asked to choose the appropriate answer in multiple choice.

Validity and reliability should be considered to have a good test. A good test is valid if it measures what is supposed to be measured. To see the validity of the test, the writer used content validity. Arikunto (2005:67) states that one of the characteristics of test validity is content validity. It means that the test is valid if it fixes with the materials that have been given to the students.

\section{RESEARCH FINDING}

In this chapter, the researcher presents finding and discussion. The discussion will be divided into: students' ability to identify the generic structure of news item text, students' ability to identify the newsworthy event of news

item text, students' ability to identify the background event of news item text and students' ability to identify the source of news item text.

1. Students' Ability to Identify the Generic Structure of News Item Text 
After the researcher checked and gave the scores for the students' answer, the researcher found that the lowest score was 4 and the highest score was 21 . Then the researcher got mean 12.4 and standard deviation 6.35.

After that, the researcher classified the students' ability into three groups (high, moderate, and low). Students' ability was categorized as high if their scores were higher than 18.75. It was categorized as moderate if their scores were in the range of 6.05 to 18.75 , and it was categorized as low if their scores were lower than 6.05 .

Finally, the researcher calculated the percentage of the students who included in each of those three groups. The result was that 6 students $(9.23 \%)$ had high ability, 57 students $(87.69 \%)$ had moderate ability, and 2 students $(3.07 \%)$ had low ability.

Based on the explanation above, it can be concluded that the students' ability to identify the generic structure of news item text was moderate. This statement was supported by the fact that $87.69 \%$ (57 students) had moderate ability. (See Appendix H)

2. Students' Ability to Identify the Newsworthy Event of News Item Text

The data on students' ability to identify generic structure of news item text demonstrated that the lowest score was 1 and the highest score was 8 . It also revealed that the mean was 4.9 and the standard deviation was 1.88 . Students' ability was categorized as high if their scores were higher than 6.78. It was categorized as moderate if their scores were in the range 3.02 to 6.78 and it was categorized as low if their scores were lower than 3.02. She calculated the percentage of students who were included in each of those three groups. The result was that 13 students $(20 \%)$ had high ability, 38 students $(58.46 \%)$ had moderate ability, and 14 students $(21.54 \%)$ had low ability.

It can be concluded that the students' ability to identify the newsworthy event of news item test was moderate. It was indicated by percentage of students whose ability was included in moderate category $58.46 \%$ (38 students).

3. Students' Ability to Identify the Background Event of News Item Text

The data on students' ability to identify the background event of news item text showed that the lowest score was 1 and the highest score was 7. It also revealed that the mean was 4.05 and the standard deviation was 1.49. Students' ability was categorized as high if their scores were higher than 5.54. It was categorized as moderate if their scores were in the range of 2.56 to 5.54 and it was categorized as low if their scores were lower than 2.56. She calculated the percentage of students who were included in each of those three groups. The result was that 10 students (15.38\%) had high ability, 45 students $(69.24 \%)$ had moderate ability, and 10 students (15.38\%) had low ability.

From the explanation above, it can be concluded that the students' ability to identify the background event of news item test was moderate. It was supported by percentage of students whose ability was included in moderate category $69.23 \%$ (45 students).

\section{Students' Ability to Identify the Source of News Item Text}

The data on students' ability to identify the source of news item text demonstrated that the lowest score 1 and the highest score was 6 . It also revealed mean was 3, 75 for mean and standard deviation was 1, 59. Students' ability was categorized as high if their scores were higher than 5, 34. It was categorized as moderate if their scores were in the range of 2, 16 to 5, 34 and it was categorized as low if their scores were lower than 2.16. She calculated the percentage of students who were included in each of those three groups. The result was that 9 students (13.83) had high ability, 40 students (61.54\%) had moderate ability, and 16 students $(24.62 \%)$ had low ability.

It can be concluded that the students' ability to identify the source of news item test was moderate. It was indicated by percentage of students whose ability was included in moderate category $61.54 \%$ (40 students).

The result of the research shows that the ability of the second year students of SMA Pertiwi 1 Padang to identify generic structure of news item test was moderate. It can be discussed more detail in each aspect of generic structure of news item text.

In term of newsworthy event, the students have mistakes in identifying the event. It is indicated from the test item number 15 in the text 5 and 18 in the text 6 . Then, in identifying the background event of the news item text, students 
was confused to choose the best answer of the test item number 21 in the text 6 . While in identifying the source of the news item test, the students found difficulties to answer the test item number 8 in the text 2 and 16 in the text 5 .

\section{CONCLUSION}

After having discussion in the previous chapter, the researcher concluded that the ability of the second year students of SMA Pertiwi 1 Padang to identify generic structure of news item text was moderate. The data described that there were 57 students $(87.69 \%)$ had moderate ability to identify the generic structure of news item text, 2 students $(3.07 \%)$ had low ability to identify the generic structure of news item text and 6 students $(9.23 \%)$ had high ability to identify the generic structure of news item text. Specifically the results of the study are as follows:

1. The ability of the second year students of SMA Pertiwi 1 Padang to identify the newsworthy event of news item text was moderate. It was proved by the fact that $58.46 \%$ of the students had moderate ability

2. The ability of the second year students of SMA Pertiwi 1 Padang to identify the background event of news item text was moderate. It was proved by the fact that $69.23 \%$ of the students had moderate ability.
It can be concluded that among of 21 items, dominant students did mistake in 5 items as stated above.

3. The ability of the second year students of SMA Pertiwi 1 Padang to identify the source of news item text was moderate. It was proved by the fact that $61.54 \%$ of the students had moderate ability.

Based on the result of the study, the researcher would like to give some suggestions as follows:

1. The teachers are expected to review the materials and give more exercises about the generic structure of news item text since the result of study shows that the students' ability to identify the generic structure was moderate.

2. The students are suggested to learn more about the generic structure of news item text and they are expect to do more exercises about it.

Since the students' ability to identify the generic structure of news item was moderate, the writer suggests other researchers to study the students' difficulties to identify the generic structure of news item text. 


\section{Bibliography}

[1]Arikunto, S. 2005. Dasar- dasar Evaluasi Pendidikan. Jakarta: Bumi Aksara.

[2]Chia, H. L. (2001). "Reading Activities for Effective Top-Down Processing". English Teaching Forum. Vol. 38 No.2 Pg. 33. Classification Essay - Everything You Need to Know. http://EzineArticles.com/?expert=Sarah_B rodie. (Accessed on February 28, 2009.

[3]Gay, L. R. (1987). Educational Research (Competencies for Analysis and Application). Third Edition. Florida: Merrill Publishing Company.

[4]Gerot, Linda and Wignell P. 1994. Making Sense of Functional Grammar. Sydney: Gerd Stagler.

[5]Hal, J. 2007. "Beginning Reporting: Story Structure”. http://www.courses.vcu.edu/ENGJeng/Beg inning reporting/writing/story structure.htm. (Accessed on April 17, 2009)

[6]Paltridge, B. 2001. Understanding Genre and Register: Implication for Language teaching. Sydney: Macquire University. (2006). Discourse analysis. New York: Continuum.
[7]Park, B. 2007. "Basic News Writing". http://www.ohlone.edu/people/bparks/basi c news writing.html

(Accessed on April 14, 2009)

[8]Stovall, James Glen. 2000. "Writing the news II'.

http://www.abacon.com/stovall/lectureosn $\underline{\text { otes.html }}$

(Accessed on April, 15, 2009)

[9]Sudarwati and Grace, E. 2005. Look Ahead: An English Course for Senior High School Students Year X. Jakarta: Erlangga.

(2007). Look Ahead: An English

Course for Senior High School Students

Year X. Jakarta: Erlangga.

Understanding Types of Text http://understandingtext.blogspot.com/sear ch/label/Abstract on text types.html (Accessed on February 28, 2009)

[10]Templeton, S. 1995. Children Literacy: Context for Meaningful Learning. New Jersey: Houghton Mifflin Company

[11]White, P.R.R. 1998. "Telling Media Tales: The News Story as Rhetoric". http://www.grammatics.com/appraisal/chp t1_telling_media_tales.doc (Accessed on April 14, 2009) 